\title{
Tropospheric modeling of acetic acid in the UK for Summer, Winter and Spring seasons using a mesoscale 3-dimensional chemistry and transport model, WRF-Chem-CRI
}

\author{
M. Anwar H. Khan a, James W. Dennis ${ }^{\mathrm{a}}$, Thomas J. Bannan ${ }^{\mathrm{b}}$, Asan Bacak ${ }^{\mathrm{b}}$, Alastair M. Booth ${ }^{\mathrm{b}}$, \\ Jennifer B.A. Muller ${ }^{\mathrm{b}}$, Douglas Lowe ${ }^{\mathrm{b}}$, Carl J. Percival ${ }^{\mathrm{c}}$, Dudley E. Shallcross ${ }^{\mathrm{a}, \mathrm{d}, *}$

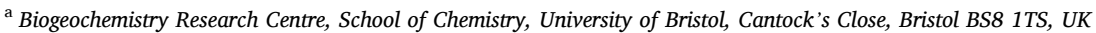 \\ ${ }^{\mathrm{b}}$ The Centre for Atmospheric Science, The School of Earth, Atmospheric and Environmental Science, The University of Manchester, Manchester M13 9PL, UK \\ ${ }^{\mathrm{c}}$ NASA Jet Propulsion Laboratory, California Institute of Technology, 4800 Oak Grove Dr, Pasadena, CA 91109, USA \\ ${ }^{\mathrm{d}}$ Department of Chemistry, University of the Western Cape, Robert Sobukwe Road, Bellville 7375, South Africa
}

\section{A R T I C L E I N F O}

\section{Keywords:}

Meteorological parameters

Diurnal trend

Seasonal variation

Anthropogenic sources

Criegee intermediates

Wet deposition

\begin{abstract}
A B S T R A C T
The measurement of acetic acid during the ClearfLo campaign for Winter 2012 and Summer 2012 in London and at the Weybourne Research Station (East Anglia), UK for Spring 2013 gives the average $\pm 1 \sigma$ mixing ratios of $45.9 \pm 31.5,25.7 \pm 14.3$ and $55.1 \pm 32.0 \mathrm{ppt}$, respectively. The WRF-Chem-CRI model was run over these three seasons and within uncertainty reproduced the data from London, with mixing ratios during Winter (32.3 \pm 25.3 ppt) and Summer $(55.1 \pm 22.6 \mathrm{ppt})$. The model's seasonality was opposite to that observed and although within the combined uncertainty of the measurement and model data it underpredicted the levels observed at Weybourne during Spring $(28.9 \pm 19.3 \mathrm{ppt})$. The model-measurement correlations of the meteorological parameters (e.g. temperature, wind direction, wind speed) were good with a correlation of $R>0.7$. The predicted diurnal trend of acetic acid resembled measurement data with a small negative bias during winter but performed less well during summer with a large positive bias and in spring with a large negative bias. The reasonable correlation of acetic acid mixing ratios with temperature was found to be similar for both measurement and model ( $R_{\text {mea- }}$ surement $=0.5, \mathrm{R}_{\text {model }}=0.6$ ) during Summer suggesting the importance of the photochemical secondary source of acetic acid which was reflected both in the measurement and the model. The key processes identified from the model results were a) missing direct anthropogenic sources of acetic acid (accounting for the lower model winter values) and b) not including its loss process by Criegee intermediates (accounting for the higher model values in summer). Comparing the weekend data with weekday data revealed a likely underpredicted source of acetic acid from vehicles. The wet deposition removal process of acetic acid was found not to be as significant in the UK as anticipated.
\end{abstract}

\section{Introduction}

Acetic acid $\left(\mathrm{CH}_{3} \mathrm{COOH}\right)$, one of the most prevalent of the carboxylic acids, contributes significantly to atmospheric free acidity in remote regions; having subsequent effects on precipitation acidity and cloud water chemistry (Keene and Galloway, 1988), which can lead to detrimental effects on ecosystems (e.g. fish, vegetation and other biota) (Burns et al., 2016). The gaseous $\mathrm{CH}_{3} \mathrm{COOH}$ has a minor effect on aerosol processes (Meng et al., 1995; Nah et al., 2018), but its concentration in the aerosol phase is sufficient to act as cloud condensation nuclei (CCN) in some special source regions such as vegetation and biomass burning, which can affect global thermal balance (Yu, 2000).

The spatial variability of the mixing ratios of $\mathrm{CH}_{3} \mathrm{COOH}$ is high (Chebbi and Carlier, 1996) and its sources and sinks are not well understood (Paulot et al., 2011; Khan et al., 2018). Concentrations of $\mathrm{CH}_{3} \mathrm{COOH}$ are generally found elevated in the urban polluted areas in contrast to the remote and rural unpolluted areas (Meng et al., 1995; Chebbi and Carlier, 1996; Khare et al., 1999). A bottom-up estimate showed that approximately $20-40 \%$ of the total sources of $\mathrm{CH}_{3} \mathrm{COOH}$ could be attributed to direct emissions including vehicular exhaust

\footnotetext{
* Corresponding author at: Biogeochemistry Research Centre, School of Chemistry, University of Bristol, Cantock's Close, Bristol BS8 1TS, UK.

E-mail address: d.e.shallcross@bristol.ac.uk (D.E. Shallcross).
} 
emissions, biomass burning and vegetation and the remaining originated from its photochemical production (Baboukas et al., 2000; von Kuhlmann et al., 2003; Ito et al., 2007; Paulot et al., 2011; Khan et al., 2018).

Acetic acid has been detected in biomass burning plumes (from natural or man-made fires i.e. forest fires, agricultural burning, domestic wood burners) and fossil fuel combustion from motor vehicles, which contributed a significant amount of direct emissions (Talbot et al., 1988; Goode et al., 2000; Christian et al., 2003; Yokelson et al., 2009; Paulot et al., 2011). Investigation of the exhaust emissions with respect to the variety of carboxylic acids showed $\mathrm{CH}_{3} \mathrm{COOH}$ was the largest contributor to the total carboxylic acid budget (Kawamura et al., 1985; Talbot et al., 1988; Zervas et al., 2001). Atmospheric conversion of enols, potentially emitted as a product of combustion, may contribute to urban acetic acid (Archibald et al., 2007). Urban emission studies have also correlated $\mathrm{CH}_{3} \mathrm{COOH}$ concentrations with primary pollutants (e.g. $\mathrm{NO}_{\mathrm{x}}$, $\mathrm{SO}_{\mathrm{x}}, \mathrm{CO}$ and particulate matter) in urban regions, suggesting a possible anthropogenic source (Granby et al., 1997a; Fisseha et al., 2006).

Biogenic sources of $\mathrm{CH}_{3} \mathrm{COOH}$, from soil and terrestrial vegetation are key contributors, estimated to produce over half of the total direct emissions (Paulot et al., 2011). While the emission from trees is known to be triggered by light, contributing to a diurnal $\mathrm{CH}_{3} \mathrm{COOH}$ cycle, crops are believed to not emit detectable quantities (Kesselmeier et al., 1998). The emission occurs via hydrolysis of acetyl-coA, as a product of the breaking down of fats and carbohydrates (Kesselmeier and Staudt, 1999). There are few studies on soil emission, but it is found that soil microbial sources have an important role in areas of low terrestrial emission (Talbot et al., 1995; Enders et al., 1992). Sanhueza and Andreae (1991) suggested that the diurnal cycle of soil emissions varies with soil type. Emissions are also increased with increasing soil moisture (Sanhueza and Andreae, 1991; Mielnik et al., 2018). Paulot et al. (2011) estimated that the inclusion of the increased acetic acid emissions due to wetting of dry soil could increase global soil emissions by $10 \%$.

From the seasonal and diurnal profiles of acetic acid, Mungall et al. (2018) suggested that the photochemical source of acetic acid is the dominant contributor to the acetic acid budget. Peroxy acetyl radicals $\left(\mathrm{CH}_{3} \mathrm{CO}_{3}\right)$ have been found to be a major chemical precursor of $\mathrm{CH}_{3} \mathrm{COOH}$, which is the most prevalent source (Jacob and Wofsy, 1988; Paulot et al., 2011; Khan et al., 2018). In rural or remote areas, these radicals react with $\mathrm{HO}_{2}$ and $\mathrm{RO}_{2}$ to form significant amounts of $\mathrm{CH}_{3} \mathrm{COOH}$ (Madronich and Calvert, 1990; Madronich et al., 1990; Hasson et al., 2004). These reactions are suggested to represent $53 \%$ and $24 \%$ of photochemical production, respectively (Paulot et al., 2011). Acetaldehyde $\left(\mathrm{CH}_{3} \mathrm{CHO}\right)$ is one of the precursors of $\mathrm{CH}_{3} \mathrm{CO}_{3}$, which is strongly emitted from the terrestrial and marine biosphere (Millet et al., 2010). Monoterpenes and isoprene are other biogenic sources, representing key precursors for $\mathrm{CH}_{3} \mathrm{CO}_{3}$ in rural and remote regions (Lee et al., 2006). Franco et al. (2020) also found a correlation of the abundance of acetic acid with isoprene and monoterpene emissions from satellite retrievals. Aqueous phase oxidation of methylglyoxal (a product of gas phase isoprene oxidation) has been proposed as a potential source of $\mathrm{CH}_{3} \mathrm{COOH}$ (Lim et al., 2005; Carlton et al., 2006). There are also anthropogenic olefin sources, including from biomass burning, vehicular exhaust and a variety of industrial emissions although they represent a small fraction of total precursors globally (Chebbi and Carlier, 1996; Paulot et al., 2011). Ozonolysis of olefins via the Criegee intermediate is an important source of $\mathrm{CH}_{3} \mathrm{COOH}$ (Calvert and Stockwell, 1983; Khan et al., 2018). Organic aerosols have recently been proposed as a potential source of $\mathrm{CH}_{3} \mathrm{COOH}$ in urban regions via photochemical degradation (Keene et al., 2015).

The atmospheric lifetime of acetic acid is believed to be around 1.6 to 1.8 days (Paulot et al., 2011; Khan et al., 2018). $\mathrm{CH}_{3} \mathrm{COOH}$ has a relatively long lifetime ( $\sim 10$ days) with respect to $\mathrm{OH}$ with this process accounting for approximately $20 \%$ of the global sink processes (Paulot et al., 2011; Khan et al., 2018). As a result of the low reactivity of $\mathrm{CH}_{3} \mathrm{COOH}$, most of its losses are attributed to dry and wet deposition
(Seinfeld and Pandis, 2016). Dry deposition is suggested to represent approximately 30\% of loss processes (Paulot et al., 2011; Khan et al., 2018). The wet deposition rate depends mostly on solubility and frequency of regional precipitation (Chebbi and Carlier, 1996). However, there is more debate as to the proportion wet deposition contributes to global loss processes. Irreversible deposition onto dust particles may contribute to $\sim 3 \%$ of global $\mathrm{CH}_{3} \mathrm{COOH}$ loss, a process suggested by Paulot et al. (2011). Uptake on dust was found to be promoted by higher humidity, with higher acetate concentrations on mineral aerosols under these conditions (Falkovich et al., 2004). Reaction with Criegee intermediates may also play a role in chemical loss (Welz et al., 2014; Chhantyal-Pun et al., 2018). A recent modeling study has suggested that it contributes up to $60 \%$ of $\mathrm{CH}_{3} \mathrm{COOH}$ chemical loss in tropical regions (Khan et al., 2018).

Having highlighted the tropospheric relevance of acetic acid and the gaps in our current understanding of its sources and sinks at a regional scale, we measure $\mathrm{CH}_{3} \mathrm{COOH}$ from two separate locations in the UK (London and Weybourne) in three time periods (Winter, Summer and Spring) to investigate the spatial, diurnal and seasonal variations of $\mathrm{CH}_{3} \mathrm{COOH}$ in these locations. We employ a regional 3-D meteorological model, WRF-Chem-CRI to simulate the distribution of $\mathrm{CH}_{3} \mathrm{COOH}$ over North-West Europe with updated chemistry and deposition parameters (Khan et al., 2018) and evaluate the production and loss of $\mathrm{CH}_{3} \mathrm{COOH}$ by comparing with the measurement data in these locations.

\section{Experimental}

\subsection{Measurement site and measurement technique}

The measurement of acetic acid was performed over three time periods covering three seasons: Winter, Summer and Spring and from two separate locations (London and Weybourne) in the UK (Table 1). Summer and winter data were measured from London during the ClearfLo project (Bohnenstengel et al., 2015), which would primarily provide insight into the chemistry and vertical structure of the urban boundary layer in London through the measurement of meteorology, gas-phase chemistry and particulate matter loading. Winter ClearfLo measurements were made in January and February 2012 and Summer measurements were made in July and August of the same year. The London site is $7 \mathrm{~km}$ west of central London, hence providing data representative of an urban environment. Spring measurements were performed at The Weybourne Atmospheric Observatory (WAO) located on the North Norfolk Coast, UK, hence providing data representing of either a rural or a marine environment depending on wind direction.

Detailed measurement descriptions of the winter and summer ClearfLo campaigns can be found in Bannan et al. (2014) and Bannan et al. (2015), respectively. A seasonal comparison of formic acid for the summer and winter campaigns can be found in Bannan et al. (2017a). Detailed measurement specifics of the Weybourne campaign can be found in Bannan et al. (2017b). All measurements used the same quadrupole iodide Chemical Ionisation Mass Spectrometer (CIMS), which was routinely calibrated for acetic acid. Calibrations were run weekly for winter and summer data collection. Post campaign acetic acid calibrations were carried out for the spring season after completion, and applied relative to the formic acid sensitivity that was regularly calibrated. This approach assumes a constant sensitivity ratio of formic to acetic acid throughout the campaigns and has been used in Le Breton et al. (2014) and Bannan et al. (2019) previously. The measurements of

Table 1

Description of acetic acid measurements.

\begin{tabular}{llll}
\hline Season & Time period & Location & Site description \\
\hline Winter & $16 / 01 / 12-08 / 02 / 12$ & London & Urban \\
Summer & $30 / 07 / 12-18 / 08 / 12$ & London & Urban \\
Spring & $14 / 03 / 13-04 / 04 / 13$ & Weybourne & Marine/Rural \\
\hline
\end{tabular}


acetic acid were made with a quadrupole mass analyser that provides measurements at unit mass resolution with possible unquantifiable interferences at $m / z 187$. Measurements are therefore presented as an upper limit of the $\mathrm{CH}_{3} \mathrm{COOH}$ at each measurement site. The meteorological data (e.g. air temperature, wind speed and wind direction) are routinely measured using a Davis Vantage Pro2 plus weather station and Gill Windsonic Anemometer, which were mounted at $3 \mathrm{~m}$ with respect to platform altitude $(21 \mathrm{~m})$. These measurements are maintained to AMOF data standards (https://amof.ac.uk/data/data-standards/) before ratification.

\subsection{Modeling technique}

WRF-Chem-CRI is a regional-scale, three-dimensional meteorological model with online chemistry. The chemical and physical processes (e.g. transport, deposition, gas-phase chemistry, emissions, photolysis and aerosol components) utilized by the model are discussed in detail elsewhere (Grell et al., 2005). The model is fully coupled, whereby the meteorology and gas-phase chemistry are integrated over the same timestep as the transport processes.

Meteorological data for model was taken from ECMWF (European Centre for Medium Range Weather Forecasts) data archives (Dee et al., 2011). Chemical boundary conditions were taken from the MOZART-4 forecast (Emmons et al., 2010). This is a global offline chemical transport model particularly suited for tropospheric studies. The biogenic emissions used in the model were calculated online by the Model of Emissions of Gases and Aerosols from Nature (MEGAN) (Guenther et al., 2006). This is a global emissions model used for estimating net emissions of gases and aerosols from soil and vegetation. It has a base resolution of $1 \mathrm{~km} \times 1 \mathrm{~km}$ grid squares, making it suitable for both regional and global studies. Variables of importance in the model are land cover, weather and atmospheric chemical composition. The inventory accounts for all known natural emission processes, which are deemed to be of atmospheric significance. There are currently primary emissions of 20 classes of BVOCs, which are then decomposed into approximately 150 species, however, certain species (ethanol, acetaldehyde, formaldehyde, formic acid and acetic acid) are grouped into the same class of emissions (bidirectional BVOC) (Guenther et al., 2012). Anthropogenic emissions have been sourced from a combination of the NAEI and TNO inventories. NAEI data (UK National Atmospheric Emissions Inventory; http://naei. defra.gov.uk/) employs a range of sources in order to calculate emissions, from national energy statistics to individual industrial plants. The data were disaggregated into different source sectors, e.g., combustion for energy production and transfer, combustion in commercial institutions, residential and agricultural sectors, combustion in industry, production processes, extraction or distribution of fossil fuels, solvent use, road transport and other transport which were combined with emission factors to estimate emissions. The NAEI data with a resolution of $1 \mathrm{~km} \times 1 \mathrm{~km}$ includes seven direct greenhouse gases addressed at the Kyoto summit, as well as a multitude of other trace gases believed to be of atmospheric significance: $\mathrm{NO}_{\mathrm{x}}, \mathrm{CO}, \mathrm{NMVOCs}$ and $\mathrm{SO}_{2}$. Where data from the NAEI was not available, the TNO MACC-III (Netherland Organisation for Applied Scientific Research, Monitoring Atmospheric Composition and Climate; Kuenen et al., 2014) data with $0.125^{\circ} \times$ $0.0625^{\circ}$ was employed to fill the gaps. The TNO MACC-III is an international project whose aim is to gather emissions from countries to ensure country compliance with EU emission ceilings and associated reductions. The chemistry scheme used is CRI-MECH (Common Representative Intermediates mechanism), a chemical mechanism describing gas-phase transformations of methane and 25 NMVOCs, via 232 chemical species participating in 638 simulated reactions (Jenkin et al., 2008; Watson et al., 2008).

The model domain covering North-West Europe with a $15 \mathrm{~km}$ horizontal resolution with a size of 134 (E-W) by 146 (N-S) grid cells and 41 vertical levels (Archer-Nicholls et al., 2014; Khan et al., 2019) was run for three seasons (e.g. Summer, Winter and Spring). The meteorological fields were re-initialised every 3 days to ensure that the divergence of the WRF-Chem-CRI meteorology from the driving ECMWF operational/ reanalysis meteorology is minimized. The model set-up has been described elsewhere (Khan et al., 2019). The simulation was carried out after the modification of the chemistry scheme and inclusion of dry deposition parameter of acetic acid as described in Khan et al. (2018).

\section{Results and discussion}

\subsection{Model evaluation: meteorology}

The atmospheric chemical processes are meteorologically dependent. Thus it is necessary to consider the meteorological aspect of the model. The most important parameters with respect to the key process conditions are temperature, wind speed and wind direction. Temperature is of greatest importance for atmospheric chemical processing as it controls the rate of chemical reactions and also alters the gas-particle phase partitioning. The Winter and Summer scenarios simulate temperature to an acceptable degree, with a respectable Pearson correlation of 0.93 and 0.90 , respectively, while the Spring scenario has a lower correlation $(R=0.78)$ (see Table 2 ). The Spring season has a slight negative bias in temperature of $-0.81^{\circ} \mathrm{C}$ whereas Winter and Summer seasons have larger negative biases of $-3.3^{\circ} \mathrm{C}$ and $-1.9^{\circ} \mathrm{C}$, respectively (Table 2).

Wind speed is modeled to a reasonable degree for all seasons, with a Pearson correlation of $0.72,0.74$ and 0.77 for Winter, Summer and Spring, respectively. The negative biases for wind speed are found for Summer and Spring seasons with -0.12 and $-0.56 \mathrm{~m} / \mathrm{s}$, respectively, but a positive bias of $1.2 \mathrm{~m} / \mathrm{s}$ is found for Winter (Table 2). The positive bias of wind speed in Winter in the European domain was previously found in the study of Zhang et al. (2013) and Brunner et al. (2015). The overestimate of wind speed in Winter leads to emissions being diluted and rapidly transported from polluted centres to background areas.

Wind direction is an important factor for the data analysis and validating the model as the prevailing wind carrying an air mass from either marine or rural terrain in the Spring and central London for Winter and Summer scenarios. The Pearson correlation (R) between modeled and measured wind direction are acceptable with $0.87,0.65$ and 0.73 for Spring, Summer and Winter, respectively, although there are large discrepancies for Winter ( $b i a s=34.5^{\circ}$, RMSE $=78.1^{\circ}$ ), Summer (bias $=-7.9^{\circ}$, RMSE $=64.1^{\circ}$ ) and Spring (bias $=9.3^{\circ}$, RMSE $=$ $34.2^{\circ}$ ) (see Table 2). The correlation during summer is low because of the lower wind speed which can increase the errors of wind direction (Jimenez and Dudhia, 2013).

\subsection{Model evaluation: seasonal variation of acetic acid}

Inspecting the model-measurement comparison plot of acetic acid during Winter reveals a weak correlation $(R=0.27)$, reasonable bias and

Table 2

Statistical summary of the WRF-Chem simulation relative to measured meteorological parameters.

\begin{tabular}{llll}
\hline Meteorological parameter & Bias & RMSE & Pearson correlation $(\mathrm{R})$ \\
\hline Spring & & & \\
Temperature $\left({ }^{\circ} \mathrm{C}\right)$ & -0.81 & 1.49 & 0.78 \\
Wind speed $(\mathrm{m} / \mathrm{s})$ & -0.56 & 2.42 & 0.77 \\
Wind direction $\left({ }^{\circ}\right)$ & 9.3 & 34.2 & 0.87 \\
Summer & & & \\
Temperature $\left({ }^{\circ} \mathrm{C}\right)$ & -1.93 & 3.0 & 0.90 \\
Wind speed $(\mathrm{m} / \mathrm{s})$ & -0.12 & 1.3 & 0.74 \\
Wind direction $\left({ }^{\circ}\right)$ & -7.9 & 64.1 & 0.65 \\
Winter & & & \\
Temperature $\left({ }^{\circ} \mathrm{C}\right)$ & -3.29 & 3.65 & 0.93 \\
Wind speed $(\mathrm{m} / \mathrm{s})$ & 1.24 & 2.05 & 0.72 \\
Wind direction $\left({ }^{\circ}\right)$ & 34.5 & 78.1 & 0.73 \\
\hline
\end{tabular}


RMSE of -13.5 ppt and $38.0 \mathrm{ppt}$, respectively (see Table 3). There are several extended periods (23/01/2012 to $25 / 01 / 2012$ and 04/02/2012 to $06 / 02 / 2012$ ) of significant under prediction of model $\mathrm{CH}_{3} \mathrm{COOH}$ (see Fig. 2). Considering the model lacks wet deposition, it is surprising that the model has a negative bias. Upon adding wet deposition to the model, the bias would become even more negative and deviate further from measured data. This suggests that there are $\mathrm{CH}_{3} \mathrm{COOH}$ sources, which remain unaccounted for in the model. This finding is consistent with the previous studies that there are many unknown sources with respect to $\mathrm{CH}_{3} \mathrm{COOH}$ processes (Chebbi and Carlier, 1996; Paulot et al., 2011; Khan et al., 2018). The missing sources may include additional vehicular or domestic cooking emissions in the urban areas (Kawamura et al., 1985; Zervas et al., 2001). There is one episode (31 January to 02 February) when the model $\mathrm{CH}_{3} \mathrm{COOH}$ is overestimated compared with the measured $\mathrm{CH}_{3} \mathrm{COOH}$ (Fig. 2). During this time, the model's wind speed is overestimated compared with the measurement (see Fig. 1), suggesting that the emission from the nearby central London transported to the measurement site has resulted in increase of model acetic acid.

Unlike the winter season, the model has a significant positive bias (29.4 ppt) and RMSE (37.2 ppt) during Summer (Table 3), which suggests that either the model is underestimating the acetic acid loss or/and overestimating secondary production of acetic acid. Inclusion of the loss due to wet deposition in the model would contribute in part to the imbalances between model-measurement, but due to lower levels of precipitation over the Summer $(9.0 \mathrm{~mm})$ compared with the Winter $(25.3$ $\mathrm{mm}$ ), this is unlikely to have such a major impact. The simulation results during Winter suggested that there are unknown missing sources of $\mathrm{CH}_{3} \mathrm{COOH}$, so overpredicting acetic acid emissions seems unlikely. Therefore, it is possible that the lack of loss processes in the model can be dominant during Summer. The Summer mixing ratios of $\mathrm{CH}_{3} \mathrm{COOH}$ would be higher due to an increase in biogenic precursors of $\mathrm{CH}_{3} \mathrm{CO}_{3}$ produced from isoprene and monoterpenes which emissions are known to increase during the months of May-August (Stewart et al., 2003). Criegee intermediates are more prevalent during the summer months, while their precursors, isoprene and monoterpenes are emitted most (Sindelarova et al., 2014; Khan et al., 2018). Criegee intermediate loss is not included in the model and is estimated to account $20-60 \%$ of chemical loss in the UK (Khan et al., 2018). Thus the inclusion of $\mathrm{CH}_{3} \mathrm{COOH}$ loss by Criegee intermediates in the model will likely contribute to reduce the imbalances between model and measurement.

The model acetic acid during Spring is underpredicted with bias -26.0 ppt and RMSE $=45.4$ ppt (Table 3) which is consistent with another study employing the WRF-Chem model and the TNO-MACC III inventory (Kuik et al., 2016). The TNO MACC-III inventory has removed agricultural emissions due to inconsistencies between countries, although it has not been made clear if this has been rectified in the inventory (Peuch et al., 2016). Agricultural emission is a major contributor to direct anthropogenic emissions, but it should be considered that the measurement station is coastal and depending on wind direction, anthropogenic emissions may not be of great significance.

WRF-Chem-CRI predictions are consistent with other models and previous expectations of $\mathrm{CH}_{3} \mathrm{COOH}$ seasonality; concentrations are higher in summer than that in winter (Talbot et al., 1988; Granby et al., 1997a; Khan et al., 2018), but the measured data showed different seasonality with higher mixing ratios of $\mathrm{CH}_{3} \mathrm{COOH}(45.9 \pm 31.5 \mathrm{ppt})$ during Winter and lower $(25.7 \pm 14.3 \mathrm{ppt})$ during Summer.

Table 3

Average measured and modeled mixing ratios of $\mathrm{CH}_{3} \mathrm{COOH}$ in different seasons.

\begin{tabular}{llll}
\hline $\mathrm{CH}_{3} \mathrm{COOH}$ & Summer & Spring & Winter \\
\hline Measured (ppt) & $25.7 \pm 14.3$ & $55.1 \pm 32.0$ & $45.9 \pm 31.5$ \\
Model (ppt) & $55.1 \pm 22.6$ & $28.9 \pm 19.3$ & $32.3 \pm 25.3$ \\
Bias (ppt) & 29.4 & -26.0 & -13.5 \\
RMSE (ppt) & 37.2 & 45.4 & 38.0 \\
Pearson correlation (R) & 0.33 & 0.10 & 0.27 \\
\hline
\end{tabular}

In addition to measured data not reflecting predicted seasonality, observed $\mathrm{CH}_{3} \mathrm{COOH}$ levels are significantly lower than many other measured data for urban, semiurban, rural, forest and marine environmental area reported by Granby et al. (1997b) and Baboukas et al. (2000).

\subsection{Model evaluation: diurnal cycles of $\mathrm{CH}_{3} \mathrm{COOH}$}

The Winter measurement data exhibits a diurnal cycle with maxima at $9 \mathrm{am}(50 \mathrm{ppt}), 6 \mathrm{pm}(62 \mathrm{ppt})$ and $10 \mathrm{pm}$ (65 ppt) and minima at $5 \mathrm{am}$ (34 ppt) and 2 pm (31 ppt) (see Fig. 3). In addition to emissions/production and loss of acetic acid, the atmospheric mixing (i.e. the rising and lowering of the boundary layer) can be responsible for the diurnal variability of acetic acid. The boundary layer is at its lowest before sunrise, then steadily increases until mid-afternoon (e.g. $3 \mathrm{pm}$ ), coinciding with the acetic acid minima. The boundary layer then steadily falls, causing species which may have built up throughout the day to descend to closer to ground level and giving an increase of surface level concentration, hence the evening/night time increase with the maximum value at $10 \mathrm{pm}$. The model predicts $\mathrm{CH}_{3} \mathrm{COOH}$ very well during daytime with maxima at $9 \mathrm{am}$ (42 ppt) and minima at 4 am (20 ppt).

We analysed the weekday and the weekend diurnal variation during the Winter period to investigate whether the direct vehicular emissions can contribute to the mixing ratios of $\mathrm{CH}_{3} \mathrm{COOH}$ during traffic rush period. The weekend measurement data of $\mathrm{CH}_{3} \mathrm{COOH}$ lack a peak during traffic rush periods but, weekday data shows two distinct peaks during weekdays at 9 am and 6 pm coinciding with traffic rush period (Fig. 4). The model also reproduced $\mathrm{CH}_{3} \mathrm{COOH}$ during traffic periods around 9 am and $6 \mathrm{pm}$. There are large underpredictions of modeled $\mathrm{CH}_{3} \mathrm{COOH}$ during traffic periods suggesting that the direct vehicular emissions are a significant contributor to the missing source of $\mathrm{CH}_{3} \mathrm{COOH}$.

The model performs worst at night during Winter, missing the second maxima at $9 \mathrm{pm}$ and there is substantial under-prediction of $\mathrm{CH}_{3} \mathrm{COOH}$ (Fig. 3). In the majority of other measured cases, $\mathrm{CH}_{3} \mathrm{COOH}$ increases with temperature and irradiance, therefore being at its peak mixing ratios during daytime. However, as is described in a study on diurnal $\mathrm{CH}_{3} \mathrm{COOH}$ mixing ratios in a cloud forest in Venezuela, $\mathrm{CH}_{3} \mathrm{COOH}$ can peak at night (Sanhueza et al., 1996). In reality, the dry deposition does not occur readily at night onto dew and wetted surfaces during winter season. The model could not account for this, therefore possibly removed too much $\mathrm{CH}_{3} \mathrm{COOH}$ in this circumstance.

Summer measurement data exhibit a less exaggerated diurnal cycle (Fig. 3), with a minimum at $5 \mathrm{am}(16 \mathrm{ppt})$ and maximum at $2 \mathrm{pm}$ (36 ppt). The model performs better, correctly predicting the minimum at 4 am (33 ppt) followed by an increase towards $12 \mathrm{pm}$ and then decline during night-time. The increase in measurement data from 9 am to $3 \mathrm{pm}$ can likely be attributed to the increase in solar radiation, causing release of biogenic precursors and photochemical reactions forming $\mathrm{CH}_{3} \mathrm{COOH}$, which is reflected in the model very well. The high positive bias throughout the daytime can be attributed to omitting the Criegee intermediate loss process. Comparing this diurnal cycle to that of urban measurements taken from another summer European urban environment at Brussels during June, the measured data bears little to no resemblance, showing peak mixing ratios at 6 am and a decrease until 10 pm (Granby et al., 1997b) The same can be said of $\mathrm{CH}_{3} \mathrm{COOH}$ measurements taken from Zurich 2002 over August and September, interestingly the measured data better resembles the cycle of $\mathrm{HCOOH}$ rather than $\mathrm{CH}_{3} \mathrm{COOH}$ for this period (Fisseha et al., 2006). The HCOOH cycle follows a more classical diurnal trend, showing evidence of biogenic and secondary anthropogenic sources (Bannan et al., 2017a). This would therefore suggest the same for $\mathrm{CH}_{3} \mathrm{COOH}$.

The measured data from the Spring season exhibits a small average diurnal fluctuation, with the maximum (61 ppt) and minimum (50 ppt) (Fig. 3). There are three maxima at $3 \mathrm{am}, 12 \mathrm{pm}$ and $9 \mathrm{pm}$ and three minima at $12 \mathrm{am}, 9 \mathrm{am}$ and $3 \mathrm{pm}$. The model predicts the slight peak at 

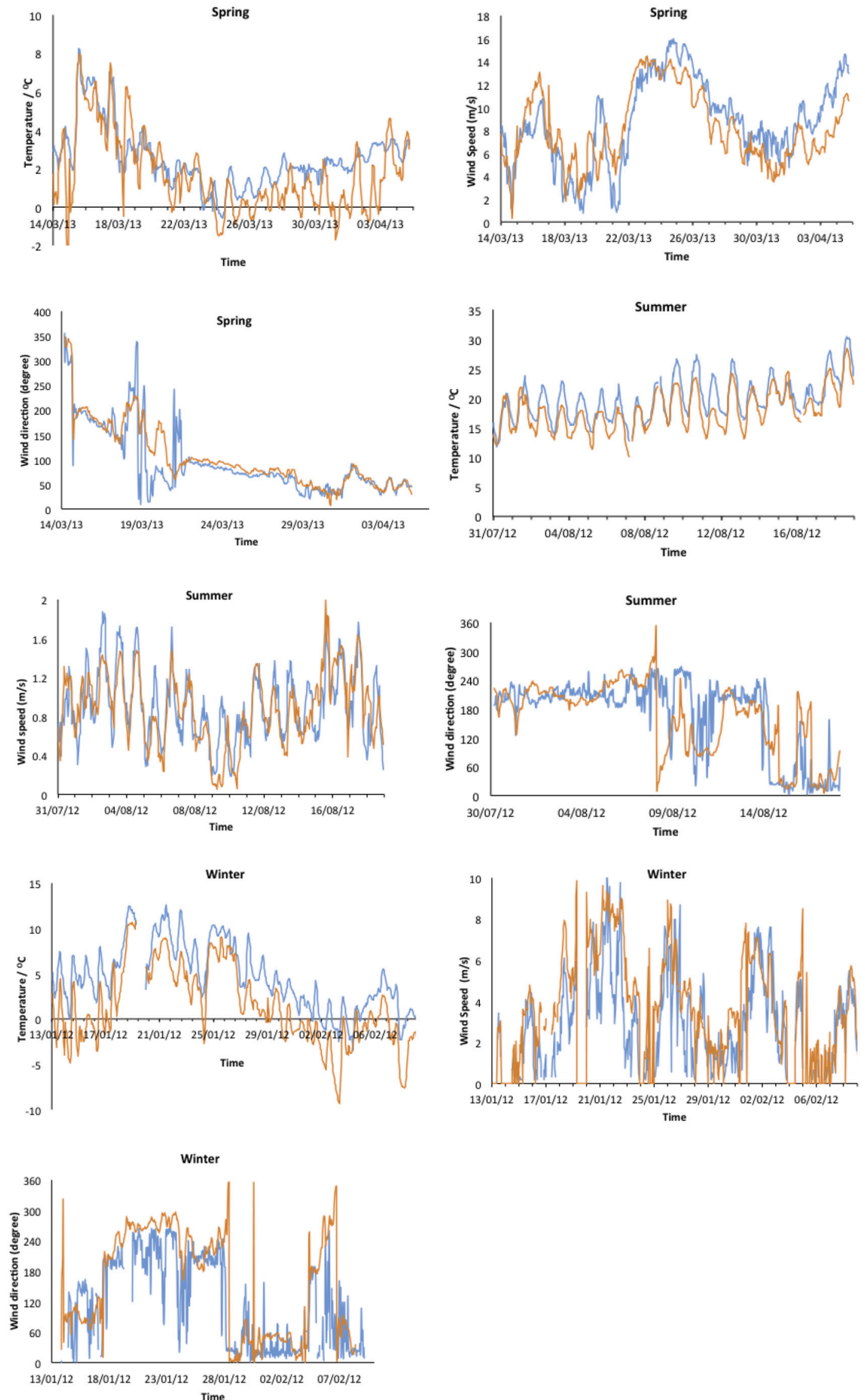

Fig. 1. Validation of model meteorological data (orange) with measured meteorological data (blue) for Spring, Summer and Winter seasons. 

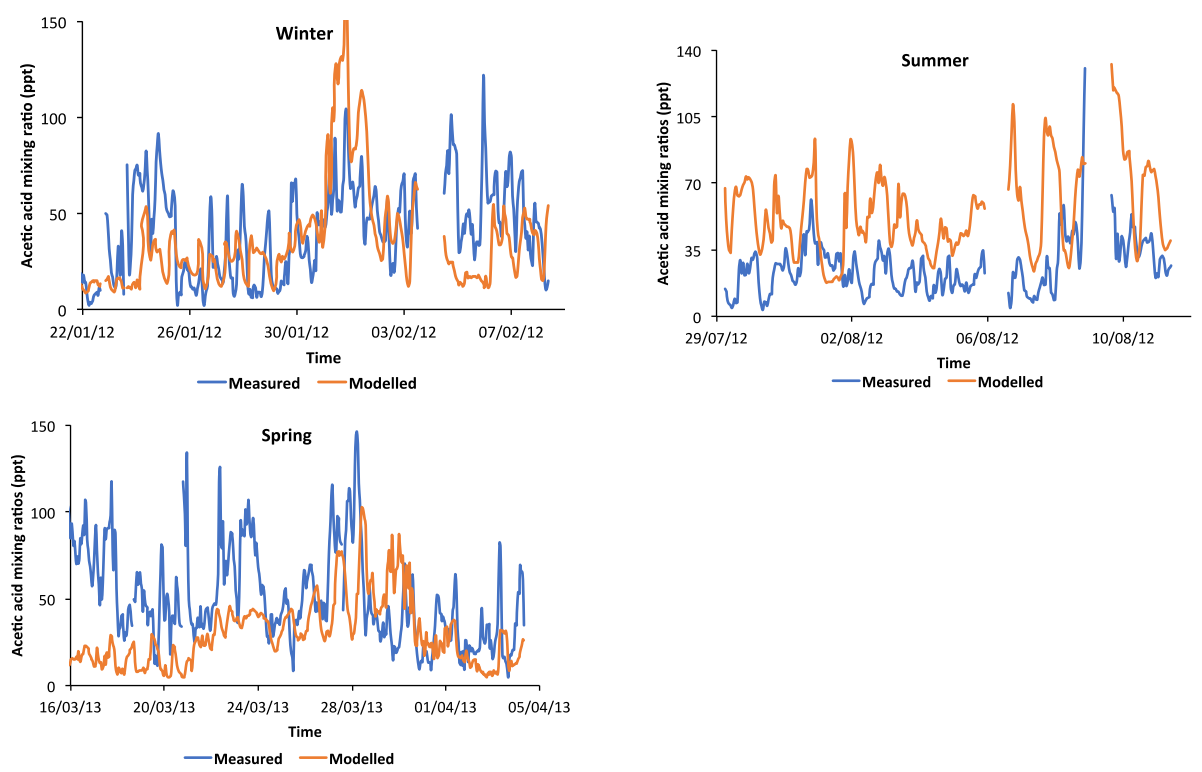

Fig. 2. Comparison of time-series plots of modeled and measured $\mathrm{CH}_{3} \mathrm{COOH}$ for winter, summer and spring seasons. Note: Some missing values during $06-07$ August, 09-10 August, and 03-04 February 2012 are due to the instrumental failures.
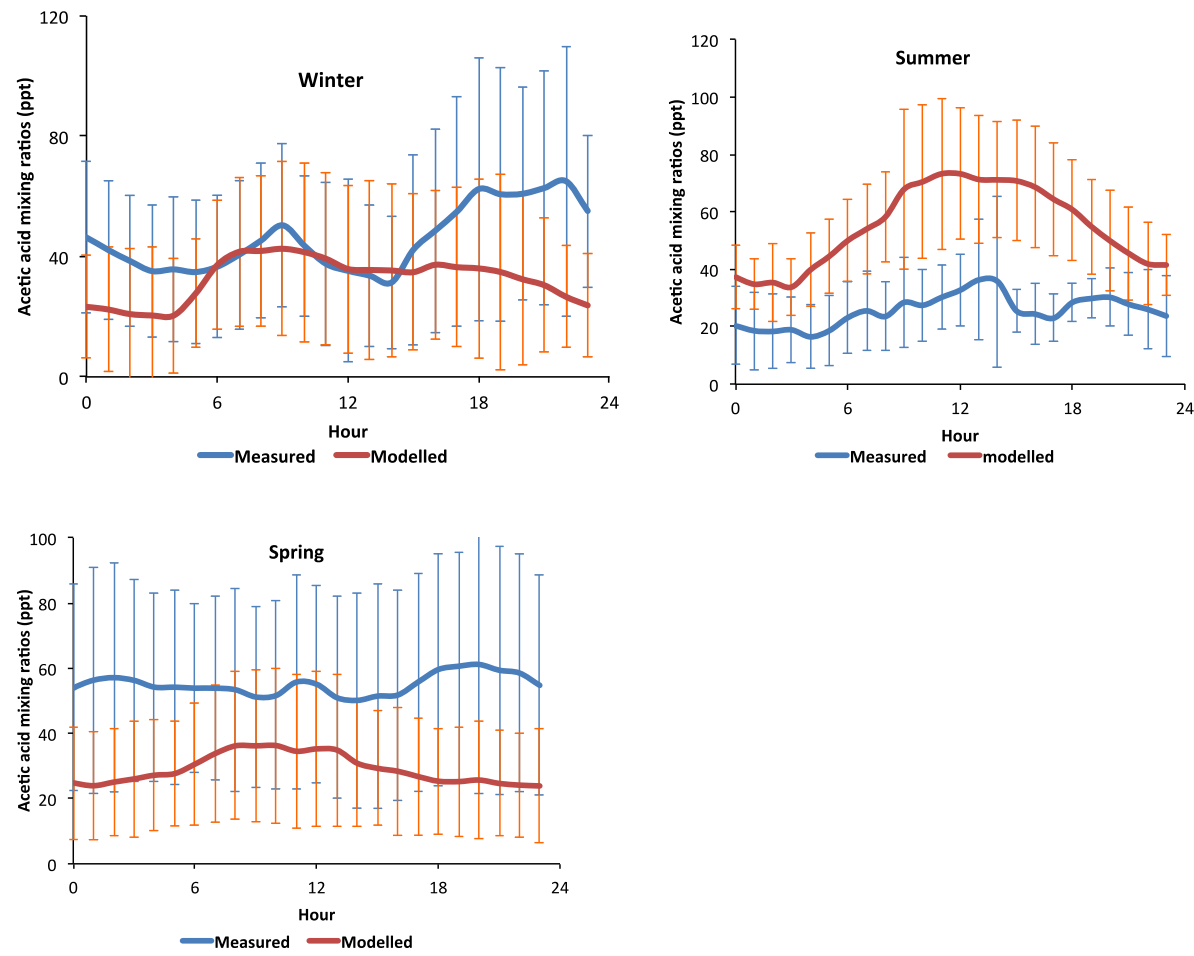

Fig. 3. Diurnal comparison plots of modeled and measured $\mathrm{CH}_{3} \mathrm{COOH}$ for Winter, Summer and Spring seasons.

$12 \mathrm{pm}$ but fail to follow the trend from $3 \mathrm{pm}$ to $12 \mathrm{am}$. This is likely due to dry deposition removing too much $\mathrm{CH}_{3} \mathrm{COOH}$ overnight. A missing marine source will cause some underprediction of model $\mathrm{CH}_{3} \mathrm{COOH}$ (Arlander et al., 1990; Khan et al., 2018). Whether or not wind direction has an impact on bias will be a good indicator as to whether this is likely, this has been explained briefly in the later Section 3.4.

3.4. Impact of meteorological parameter for the deviation of the model data from measurement data

One of the shortcomings identified in the model runs has been the lack of wet deposition. Fig. 5a shows a prolonged period of rainfall on $31 / 0712$ am to 5 am (total rainfall $=3.4 \mathrm{~mm}$ ). There is a visible decrease in measured $\mathrm{CH}_{3} \mathrm{COOH}$ during this period, with mixing ratios falling to $4 \mathrm{ppt}$, the lowest of the entire Summer. This decrease in only reflected to a slight extent in model run. Fig. $5 \mathrm{~b}$ shows two further periods of rainfall: $24 / 018 \mathrm{am}$ to $2 \mathrm{pm}$ (total rainfall $=5.7 \mathrm{~mm}$ ) and 26/01 $5 \mathrm{am}$ to $9 \mathrm{am}$ (rainfall $=2 \mathrm{~mm}$ ) during winter period. In the first case, there is a drop in $\mathrm{CH}_{3} \mathrm{COOH}$ levels slightly greater than that of the modeled data, but this does not cause significant deviation. The second rainfall period exhibits little to no decrease in measured $\mathrm{CH}_{3} \mathrm{COOH}$ and hence little deviation from the model. This period is actually shown to 

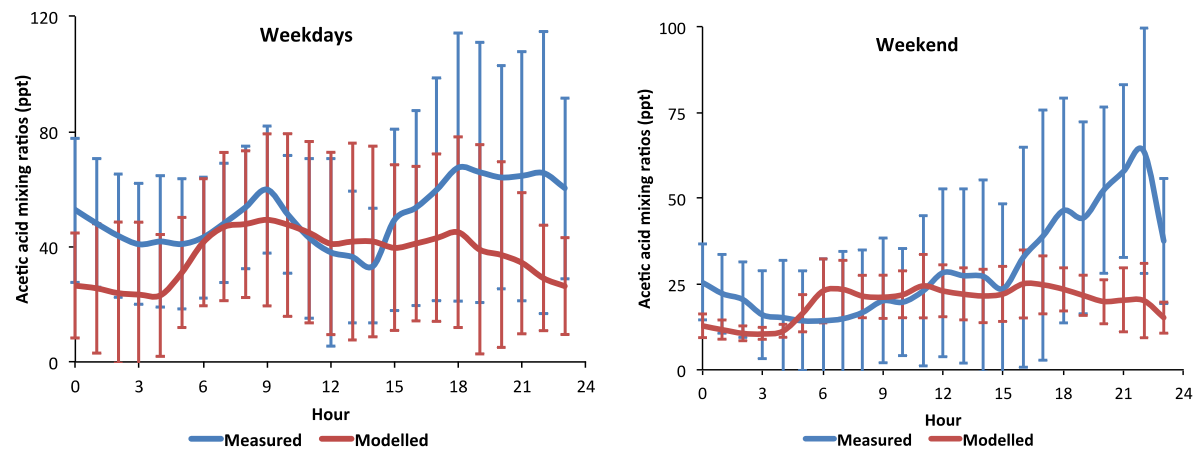

Fig. 4. Comparison of the weekday and weekend diurnal cycle of measured and modeled $\mathrm{CH}_{3} \mathrm{COOH}$ during Winter season.

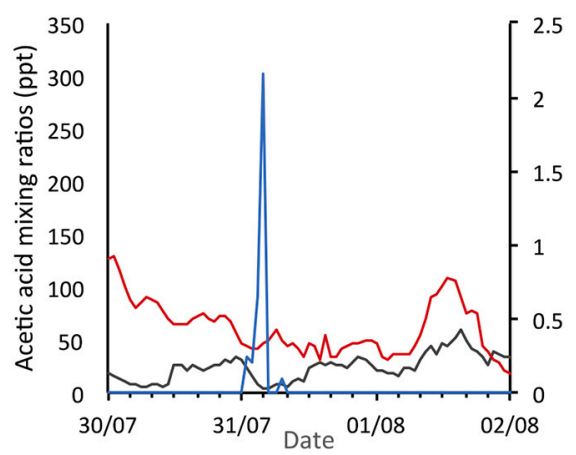

(a)

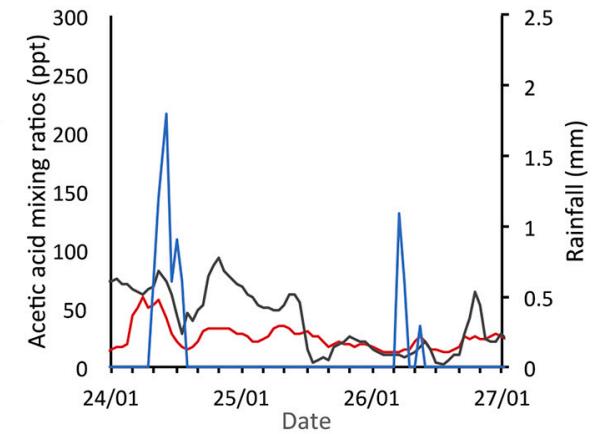

(b)

Fig. 5. Measured (black) and modeled (red) $\mathrm{CH}_{3} \mathrm{COOH}$ mixing ratios plotted against rainfall (blue) during (a) Summer and (b) Winter.
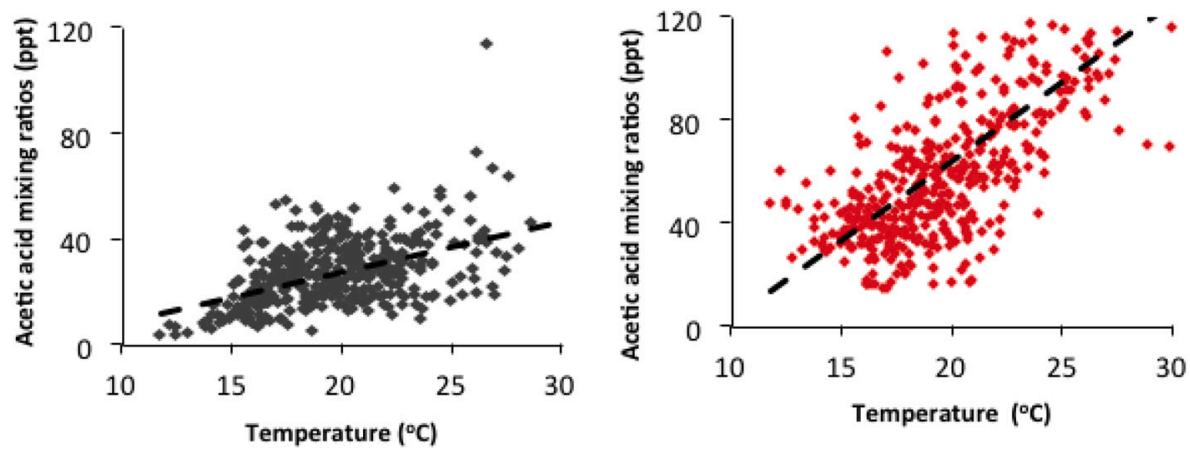

(a)
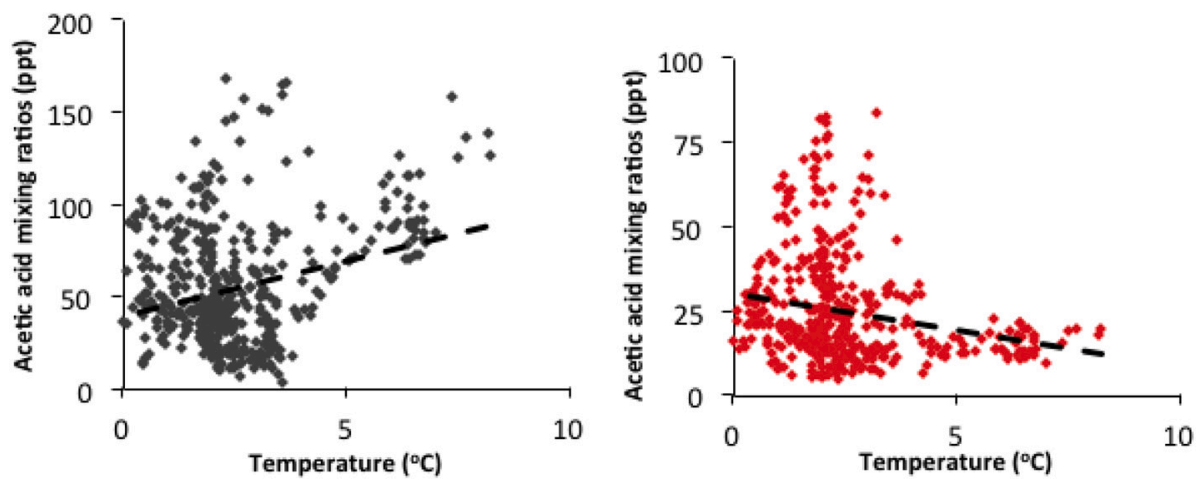

(b)

Fig. 6. Measured (black) and modeled (red) $\mathrm{CH}_{3} \mathrm{COOH}$ mixing ratios plotted against temperature for (a) summer (b) spring season. 

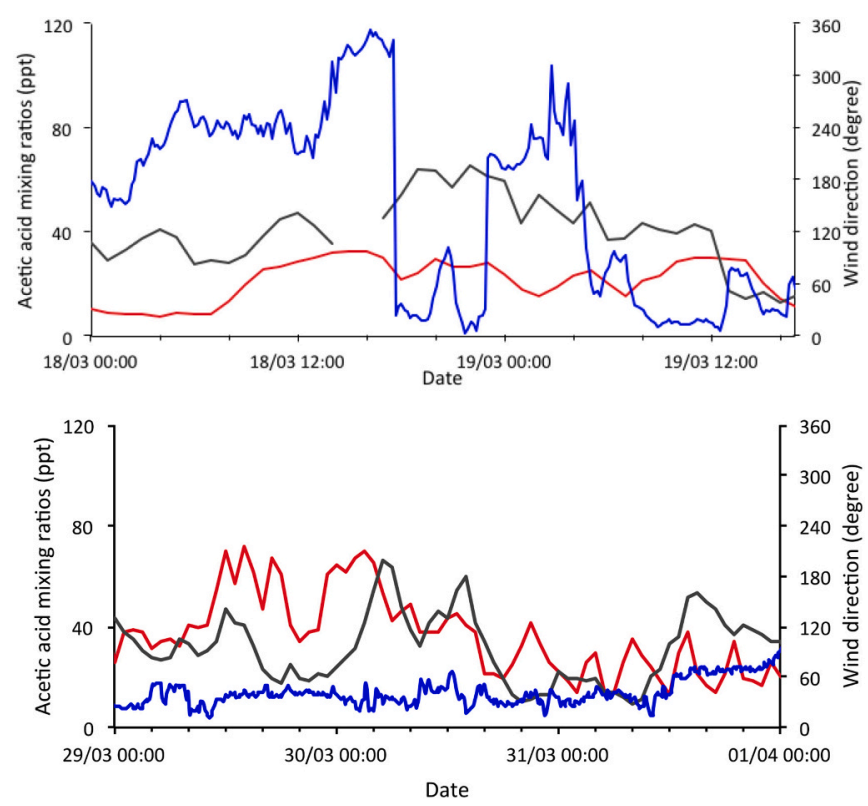

Fig. 7. Measured (black) and modeled (red) $\mathrm{CH}_{3} \mathrm{COOH}$ mixing ratios over the Spring period 18/03-19/03 and 29/03-01/04. Measured wind direction is plotted with blue lines on the secondary axis.

have one of the highest correlations of the entire period $(R=0.74)$ suggesting that rainfall does not have a significant impact on the mixing ratios of $\mathrm{CH}_{3} \mathrm{COOH}$ in the UK. It does not seem likely that wet deposition contributing $30-50 \%$ of global loss (Paulot et al., 2011; Khan et al., 2018) is representative of loss in the surface levels of UK urban areas.

There is some correlation of acetic acid with temperature during summer and spring seasons, as suggested in a study conducted in Denmark (Granby et al., 1997a, 1997b). Both Summer and Spring measured data exhibit a modest correlation with measured temperature throughout the seasons $\left(R_{\text {summer }}=0.5, R_{\text {spring }}=0.3\right.$ ) (Fig. 6). These values are fairly consistent with the work of Granby et al. (1997a, 1997b) with a slightly better correlation in the Summer than in the Spring. This is reproduced well in the model during Summer $\left(R_{\text {summer }}=\right.$ 0.6) (Fig. 6a). Spring model run fails to follow the slight trend shown in the measured data with a correlation of $R_{\text {spring }}=-0.2$ (Fig. 6b). This anti-correlation can be explained by the large disagreement between modeled and measured temperature (mostly model underestimation) during the spring season (see Fig. 1). Winter measured data shows a very slight negative temperature correlation of -0.17 . The model gives a negative correlation of -0.5 , which is too far from the measured correlation to be considered an accurate representation. However, this prediction is closer to the winter value $(R=-0.49)$ given by Granby et al. (1997a, 1997b).

At the Weybourne measurement site, northern winds would carry clean marine air over the site, whereas south-westerly and southeasterly winds transport polluted air from London over the site (Lee et al., 2009). During Spring, there are many episodes when modelmeasurement deviations occur, one of which occurs during the period 18/03 6 am to 19/03 6 am (Fig. 7). During this time, a significant fraction of south easterly wind carrying air mass from London may contain acetic acid (possibly derived from direct anthropogenic emissions), hence the deviation. A plume from London can be seen passing

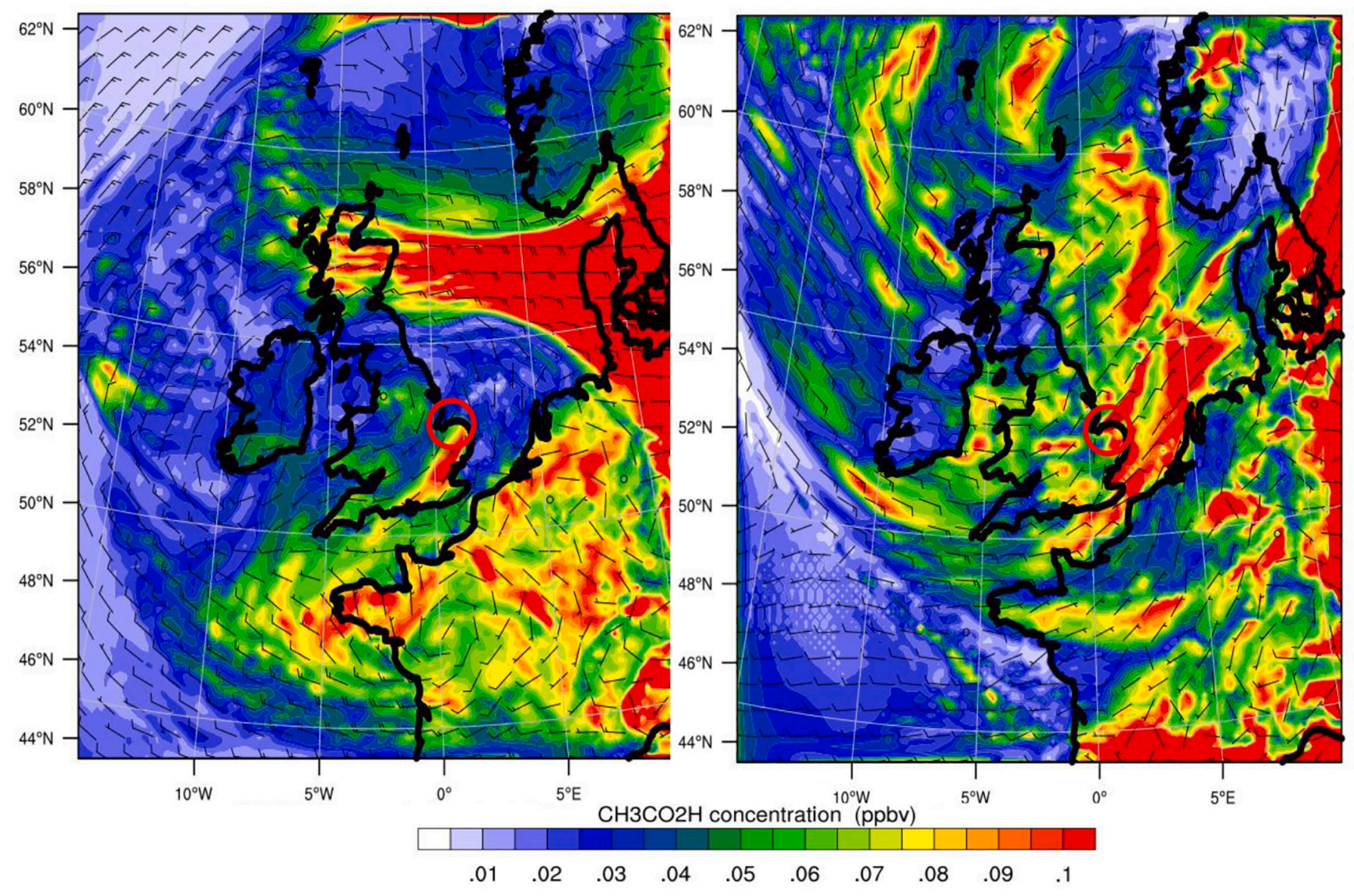

Fig. 8. Distribution plot of $\mathrm{CH}_{3} \mathrm{COOH}$ mixing ratios at 18/03 $3 \mathrm{pm}$ (left) and 30/03 12 am (right). The Weybourne measurement site is approximately circled (red marked). 
over the Weybourne site in Fig. 8. The modeled wind direction during $18 / 033 \mathrm{pm}$ at the Weybourne site $\left(230^{\circ}\right)$ is not consistent with the measurement at this time $\left(320^{\circ}\right)$. At $12 \mathrm{pm}$ there is a measured $\mathrm{CH}_{3} \mathrm{COOH}$ peak, which coincides with a wind direction of $220^{\circ}$, until wind direction changes shortly afterwards and levels drop. Due to desynchronization, it is likely the plume in reality passed over the measurement site a few hours earlier than predicted by the model.

Inspecting the time period of 29/03-01/04 with a better correlation than the remainder of the period, a relatively consistent wind direction of $25-50^{\circ}$ is measured until $31 / 0312 \mathrm{pm}$, when winds shift to $50-90^{\circ}$ (Fig. 7). The model seems to correctly predict wind direction to a good approximation for the entire period (see Fig. 1). As the Spring data were collected at a more remote measurement site, its low modeling performance could be explained by wind direction calculations, with polluted plumes causing a more exaggerated deviation than at the other site in London. The dependence of the measured $\mathrm{CH}_{3} \mathrm{COOH}$ on anthropogenic emissions will cause further deviation from the model as well. During periods of consistent wind direction, the model seems to cope far better and predicts trends to a better degree, with less desynchronization. Bias is clearly negative during this period and there are periods of both under and over prediction, however these periods of improved modeling are too infrequent to gather much information on whether marine sources are a likely contributor.

Low temperatures can be responsible for stagnant weather conditions, resulting in low wind speed and elevated trace gas concentrations. This was observed by Fisseha et al. (2006) in a Spring study in Zurich. The Winter measured data showed a negative correlation with respect to wind speed and temperature $\left(\mathrm{R}_{\text {Wind }}=-0.25, \mathrm{R}_{\text {Temp }}=-0.17\right)$ which can explain the high mixing ratios of acetic acid during Winter. The model run had a lower negative correlation with wind speed $\left(\mathrm{R}_{\text {Wind }}=-0.10\right)$, but higher negative correlation with temperature $\left(R_{T e m p}=-0.5\right)$ suggesting that the model may not have reflected this process effectively.

\section{Conclusion}

WRF-Chem-CRI was used to predict acetic acid in UK, which was compared against measured data taken during the ClearfLo campaign in Winter 2012 and Summer 2012 and in Weybourne, UK during Spring 2013. The model was able to predict diurnal trends to an acceptable degree, however, failed at predicting its seasonality. The model seasonality (Summer maximum followed by the Winter and Spring) predictions are consistent with other studies, but an unexpected seasonality trend for measured data was revealed, with the clean Spring (Weybourne) having the highest average, followed by the Winter and Summer (London). Intermittent periods of over $24 \mathrm{~h}$, during which model output and measurement data were well synchronized, were noted, in some cases with a correlation coefficient exceeding 0.7. Vehicular emissions could be responsible for significant quantities of acetic acid in urban regions. Previous urban studies have been carried out in regions where $\mathrm{CH}_{3} \mathrm{COOH}$ is much higher, with mixing ratios of several ppb where a contribution in the order of $10 \mathrm{ppt}$ would not have a large impact. However, urban measurements in the UK are shown to be much lower (Winter average $=45.9 \mathrm{ppt}$, Summer average $=25.1 \mathrm{ppt}$ ), meaning a relatively low vehicular contribution could have a greater impact on the diurnal cycle. While some precursors were included in the model, underprediction during weekday at 9 am and $6 \mathrm{pm}$ in the winter suggests that direct vehicular emissions could be an important source. Criegee loss could be a significant loss process during the summer months. This was not included in the model. The species' precursors are produced most during this period meaning associated loss processes would increase during this time. The significant Summer overprediction by the model would benefit from this addition. It has been suggested that the wet deposition process, while a significant contributor to $\mathrm{CH}_{3} \mathrm{COOH}$ loss globally, may not have such a major influence in lower concentration regions with moderate precipitation. Periods of rainfall only caused minor deviation from the model on most occasions. Measured $\mathrm{CH}_{3} \mathrm{COOH}$ exhibited a modest temperature correlation for Summer $\left(R_{\text {Summer }}=0.5\right)$ and Spring $\left(\mathrm{R}_{\text {Spring }}=0.3\right)$, while winter data showed a negative correlation. The negative correlation in Winter is consistent with the argument that the stagnant conditions caused by low temperature caused high concentrations for the winter period.

\section{Declaration of competing interest}

None.

\section{Acknowledgement}

We thank Mr. James Groves, Mr. Dan Walker and Dr. Barbara Brooks for providing the meteorological data from the three campaigns. MAHK and DES thank NERC (grant code-NE/K004905/1), Bristol ChemLabS and the Primary Science Teaching Trust under whose auspices various aspects of this work was supported. AB work was carried out under the auspices of the Turkish Accelerator Radiation Laboratory (TARLA) and was supported by Turkish Science Council (TUBITAK). CJP work was carried out at Jet Propulsion Laboratory, California Institute of Technology, under contract with the National Aeronautics and Space Administration (NASA), and was supported by the Upper Atmosphere Research and Tropospheric Chemistry Programs. (C) 2020 all rights reserved.

\section{References}

Archer-Nicholls, S., Lowe, D., Utembe, S., Allan, J., Zaveri, R.A., Fast, J.D., Hodnebrog, Ø., van der Gon, H.D., McFiggans, G., 2014. Gaseous chemistry and aerosol mechanism developments for version 3.5.1 of the online regional model. WRF-Chem. Geosci. Model Dev. 7, 2557-2579.

Archibald, A.T., McGillen, M.R., Taatjes, C.A., Percival, C.J., Shallcross, D.E., 2007. Atmospheric transformation of enols: a potential secondary source of carboxylic acids in the urban troposphere. Geophys. Res. Lett. 34, L21801.

Arlander, D.W., Cronn, D.R., Farmer, J.C., Menzia, F.A., Westberg, H.H., 1990. Gaseous oxygenated hydrocarbons in the remote marine troposphere. J. Geophys. Res. Atmos. 95, 16391-16403.

Baboukas, E.D., Kanakidou, M., Mihalopoulos, N., 2000. Carboxylic acids in gas and particulate phase above the Atlantic Ocean. J. Geophys. Res. 105, 14459-14471.

Bannan, T.J., Bacak, A., Muller, J.B., Booth, A.M., Jones, B., Le Breton, M., Leather, K.E., Ghalaieny, M., Xiao, P., Shallcross, D.E., Percival, C.J., 2014. Importance of direct anthropogenic emissions of formic acid measured by a chemical ionisation mass spectrometer (CIMS) during the Winter ClearfLo Campaign in London, January 2012. Atmos. Environ. 83, 301-310.

Bannan, T.J., Booth, A.M., Bacak, A., Muller, J.B., Leather, K.E., Le Breton, M., Jones, B., Young, D., Coe, H., Allan, J., Visser, S., Slowik, J.G., Furger, M., Prévôt, A.S.H., Lee, J., Dunmore, R.E., Hopkins, J.R., Hamilton, J.F., Lewis, A.C., Whalley, L.K., Sharp, T., Stone, D., Heard, D.E., Fleming, Z.L., Leigh, R., Shallcross, D.E., Percival, C.J., 2015. The first UK measurements of nitryl chloride using a chemical ionization mass spectrometer in central London in the summer of 2012, and an investigation of the role of $\mathrm{Cl}$ atom oxidation. J. Geophys. Res. Atmos. 120, 5638-5657.

Bannan, T.J., Murray Booth, A., Le Breton, M., Bacak, A., Muller, J.B., Leather, K.E., Khan, M.A.H., Lee, J.D., Dunmore, R.E., Hopkins, J.R., Fleming, Z.L., Sheps, L., Taatjes, C.A., Shallcross, D.E., Percival, C.J., 2017a. Seasonality of formic acid $(\mathrm{HCOOH})$ in London during the ClearfLo campaign. J. Geophys. Res. Atmos. 122, $12-488$.

Bannan, T.J., Bacak, A., Le Breton, M., Flynn, M., Ouyang, B., McLeod, M., Jones, R., Malkin, T.L., Whalley, L.K., Heard, D.E., Bandy, B., Khan, M.A.H., Shallcross, D.E., Percival, C.J., 2017b. Ground and airborne UK measurements of nitryl chloride: an investigation of the role of $\mathrm{Cl}$ atom oxidation at Weybourne atmospheric observatory. J. Geophys. Res. Atmos. 122, 11-154.

Bannan, T.J., Khan, M.A.H., Le Breton, M., Priestley, M., Worrall, S.D., Bacak, A., Marsden, N.A., Lowe, D., Pitt, J., Allen, G., Topping, D., Coe, H., McFiggans, G., Shallcross, D.E., Percival, C.J., 2019. A large source of atomic chlorine from ClNO2 photolysis at a UK landfill site. Geophys. Res. Lett. 46, 8508-8516.

Bohnenstengel, S.I., Belcher, S.E., Aiken, A., Allan, J.D., Allen, G., Bacak, A., Bannan, T. J., Barlow, J.F., Beddows, D.C.S., Bloss, W.J., Booth, A.M., Chemel, C., Coceal, O., Di Marco, C.F., Dubey, M.K., Faloon, K.H., Fleming, Z.L., Furger, M., Gietl, J.K., Graves, R.R., Green, D.C., Grimmond, C.S.B., Halios, C.H., Hamilton, J.F., Harrison, R.M., Heal, M.R., Heard, D.E., Helfter, C., Herndon, S.C., Holmes, R.E., Hopkins, J.R., Jones, A.M., Kelly, F.J., Kotthaus, S., Langford, B., Lee, J.D., Leigh, R. J., Lewis, A.C., Lidster, R.T., Lopez-Hilfiker, F.D., McQuaid, J.B., Mohr, C., Monks, P. S., Nemitz, E., Ng, N.L., Percival, C.J., Prévôt, A.S.H., Ricketts, H.M.A., Sokhi, R., Stone, D., Thornton, J.A., Tremper, A.H., Valach, A.C., Visser, S., Whalley, L.K., Williams, L.R., Xu, L., Young, D.E., Zotter, P., 2015. Meteorology, air quality, and health in London: the ClearfLo project. Bull. Amer. Meteor. Soc. 96, 779-804. 
Brunner, D., Savage, N., Jorba, O., Eder, B., Giordano, L., Badia, A., Balzarini, A., Baro, R., Bianconi, R., Chemel, C., Curci, G., Forkel, R., Jimenez-Guerrero, P., Hirtl, M., Hodzic, A., Honzak, L., Im, U., Knote, C., Makar, P., Manders-Groot, A., van Meijgaard, E., Neal, L., Perez, J.L., Pirovano, G., Jose, R.S., Schroder, W., Sokhi, R.S., Syrakov, D., Torian, A., Tuccella, P., Werhahn, J., Wolke, R., Yahya, K., Zabkar, R., Zhang, Y., Hogrefe, C., Galmarini, S., 2015. Comparative analysis of meteorological performance of coupled chemistry-meteorology models in the context of AQMEII phase 2. Atmos. Environ. 115, 470-498.

Burns, D.A., Aherne, J., Gay, D.A., Lehmann, C.M.B., 2016. Acid rain and its environmental effects: recent scientific advances. Atmos. Environ. 146, 1-4.

Calvert, J.G., Stockwell, W.R., 1983. Acid generation in the troposphere by gas phase chemistry. Environ. Sci. Technol. 17, 428-443.

Carlton, A.G., Turpin, B.J., Lim, H.-J., Altieri, K.E., Seitzinger, S., 2006. Link between isoprene and secondary organic aerosol (SOA):Pyruvic acid oxidation yields low volatility organic acids in clouds. Geophys. Res. Lett. 33, L06822.

Chebbi, A., Carlier, P., 1996. Carboxylic acids in the troposphere, occurrence, sources and sinks: a review. Atmos. Environ. 30, 4233-4249.

Chhantyal-Pun, R., Rotavera, B., McGillen, M.R., Khan, M.A.H., Eskola, A.J., Caravan, R. L., Blacker, L., Tew, D.P., Osborn, D.L., Percival, C.J., Taatjes, C.A., Shallcross, D.E., Orr-Ewing, A.J., 2018. Criegee intermediate reactions with carboxylic acids; A potential source of secondary organic aerosol in the atmosphere. ACS Earth Space Chem. 2, 833-842.

Christian, T.J., Kleiss, B., Yokelson, R.J., Holzinger, R., Crutzen, P.J., Hao, W.M., Saharjo, B.H., Ward, D.E., 2003. Comprehensive laboratory measurements of biomass-burning emissions: 1. Emissions from Indonesian, African and other fuels. J. Geophys. Res. 108, 4719.

Dee, D.P., Uppala, S.M., Simmons, A.J., Berrisford, P., Poli, P., Kobayashi, S., Andrae, U. Balmaseda, M.A., Balsamo, G., Bauer, P., Bechtold, P., Beljaars, A.C.M., van de Berg, L., Bidlot, J., Bormann, N., Delsol, C., Dragani, R., Fuentes, M., Geer, A.J., Haimberger, L., Healy, S.B., Hersbach, H., Hólm, E.V., Isaksen, L., Kallberg, P., Köhler, M., Matricardi, M., McNally, A.P., Monge-Sanz, B.M., Morcrette, J.-J., Park, B.-K., Peubey, G., de Rosnay, P., Tavolato, C., Thépaut, J.-N., Vitart, F., 2011. The ERA-interim reanalysis: configuration and performance of the data assimilation system. Q. J. Roy. Soc. 137, 553-597.

Emmons, L.K., Walters, S., Hess, P.G., Lamarque, J.-F., Pfister, G.G., Fillmore, D., Granier, C., Guenther, A., Kinnison, D., Laepple, T., Orlando, J., Tie, X., Tyndall, G., Wiedinmyer, C., Baughcum, S.L., Kloster, S., 2010. Description and evaluation of the model for ozone and related chemical tracers, version 4 (MOZART-4). Geosci. Model Dev. 3, 43-67.

Enders, G., Dlugi, R., Steinbrecher, R., Clement, B., Daiber, R., Eijk, J.V., Gäb, S., Haziza, M., Helas, G., Herrmann, U., Kessel, M., Kesselmeier, J., Kotzias, D., Kourtidis, K., Kurth, H.-H., McMillen, R.T., Roider, G., Schürmann, W., Teichmann, U., Torres, L., 1992. Biosphere/atmosphere interactions: Integrated research in a European coniferous forest ecosystem. Atmos. Environ. 26A, 171-189.

Falkovich, A.H., Schkolnik, G., Ganor, E., Rudich, Y., 2004. Adsorption of organic compounds pertinent to urban environments onto mineral dust particles. J. Geophys. Res. 109, D02208.

Fisseha, R., Dommen, J., Gaeggeler, K., Weingartner, E., Samburova, V., Kalberer, M., Baltensperger, U., 2006. Online gas and aerosol measurement of water soluble carboxylic acids in Zurich. J. Geophys. Res. 111, D12316.

Franco, B., Clarisse, L., Stavrakou, T., Müller, J.-F., Taraborrelli, D., Hadji-Lazaro, J., Hannigan, J.W., Hase, F., Hurtmans, D., Jones, N., Lutsch, E., Mahieu, E., Ortega, I., Schneider, M., Strong, K., Vigouroux, C., Clerbaux, C., Coheur, P.-F., 2020. Spaceborne measurements of formic and acetic acids: a global view of the regional sources. Geophys. Res. Lett. 47, GL086239.

Goode, J.G., Yokelson, R.J., Ward, D.E., Susott, R.A., Babbitt, R.E., Davies, M.A., Hao, W. M., 2000. Measurements of excess $\mathrm{O}_{3}, \mathrm{CO}_{2}, \mathrm{CO}, \mathrm{CH}_{4}, \mathrm{C}_{2} \mathrm{H}_{4}, \mathrm{C}_{2} \mathrm{H}_{2}, \mathrm{HCN}, \mathrm{NO}, \mathrm{NH}_{3}$, $\mathrm{HCOOH}, \mathrm{CH}_{3} \mathrm{COOH}, \mathrm{HCHO}$ and $\mathrm{CH}_{3} \mathrm{OH}$ in 1997 Alaskan biomass burning plumes by airborne Fourier transform infrared spectroscopy (AFTIR). J. Geophys. Res. 105, 22147-22166.

Granby, K., Egeløv, A.H., Nielsen, T., Lohse, C., 1997a. Carboxylic acids: seasonal variation and relation to chemical and meteorological parameters. J. Atmos. Chem. 28, 195-207.

Granby, K., Christensen, C.S., Lohse, C., 1997b. Urban and semi-rural observations of carboxylic acids and carbonyls. Atmos. Environ. 31, 1403-1415.

Grell, G.A., Peckkam, S.E., Schmitz, R., McKeen, S.A., Frost, G., Skamarock, W.C., Eder, B., 2005. Fully coupled 'online' chemistry within the WRF model. Atmos. Environ. 39, 6957-6975.

Guenther, A., Karl, T., Harley, P., Wiedinmyer, C., Palmer, P.I., Geron, C., 2006. Estimates of global terrestrial isoprene emissions using MEGAN (Model of Emissions of gases and Aerosols from Nature). Atmos. Chem. Phys. 6, 3181-3210.

Guenther, A.B., Jiang, X., Heald, C.L., Sakulyanontvittaya, T., Duhl, T., Emmons, L.K., Wang, X., 2012. The model of emissions of gases and aerosols from nature version 2.1 (MEGAN2.1): an extended and updated framework for modeling biogenic emissions. Geosci. Model Dev. 5, 1471-1492.

Hasson, A.S., Tyndall, G.S., Orlando, J.J., 2004. A product yield study of the reaction of $\mathrm{HO}_{2}$ radicals with ethyl peroxy $\left(\mathrm{C}_{2} \mathrm{H}_{5} \mathrm{O}_{2}\right)$, acetyl peroxy $\left(\mathrm{CH}_{3} \mathrm{C}(\mathrm{O}) \mathrm{O}_{2}\right)$, and acetonyl peroxy $\left(\mathrm{CH}_{3} \mathrm{C}(\mathrm{O}) \mathrm{CH}_{2} \mathrm{O}_{2}\right)$ radicals. J. Phys. Chem. A 108, 5979-5989.

Ito, A., Sillman, S., Penner, J.E., 2007. Effects of additional nonmethane volatile organic compounds, organic nitrates and direct emissions of oxygenated organic species on global tropospheric chemistry. J. Geophys. Res. 112, D06309.

Jacob, D.J., Wofsy, S.C., 1988. Photochemistry of biogenic emissions over the Amazon forest. J. Geophys. Res. Atmos. 93, 1477-1486.

Jenkin, M.E., Watson, L.A., Utembe, S.R., Shallcross, D.E., 2008. A common representative intermediates (CRI) mechanism for VOC degradation. Part 1: gas phase mechanism development. Atmos. Environ. 42, 7185-7195.
Jimenez, P.A., Dudhia, J., 2013. On the ability of the WRF model to reproduce the surface wind direction over complex terrain. J. Appl. Meteorol. Climatol. 52, 1610-1617.

Kawamura, K., Ng, L.-L., Kaplan, I.R., 1985. Determination of organic acids $\left(\mathrm{C}_{1}-\mathrm{C}_{10}\right)$ in the atmosphere, motor exhausts and engine oils. Environ. Sci. Technol. 19, 1082-1086.

Keene, W.C., Galloway, J.N., 1988. The biogeochemical cycling of formic and acetic acids through the troposphere: an overview of current understanding. Tellus 40B, 322-334.

Keene, W.C., Galloway, J.N., Likens, G.E., Deviney, F.A., Mikkelsen, K.N., Moody, J.L., Maben, J.R., 2015. Atmospheric wet deposition in remote regions: Benchmarks for environmental change. J. Atmos. Sci. 72, 2947-2978. https://doi.org/10.1175/JASD-14-0378.1.

Kesselmeier, J., Staudt, M., 1999. Biogenic volatile organic compounds (VOC): an overview on emission, physiology and ecology. J. Atmos. Chem. 33, 23-88.

Kesselmeier, J., Bode, K., Gerlach, C., Jork, E.-M., 1998. Exchange of atmospheric formic and acetic acids with trees and crop plants under controlled chamber and purified air conditions. Atmos. Environ. 32, 1765-1775.

Khan, M.A.H., Lyons, K., Chhantyal-Pun, R., McGill, M.R., Caravan, R.L., Taatjes, C.A., Orr-Ewing, A.J., Percival, C.J., Shallcross, D.E., 2018. Investigating the tropospheric chemistry of acetic acid using the global 3-D chemistry transport model, STOCHEMCRI. J. Geophys. Res. Atmos. 123, 6267-6281.

Khan, M.A.H., Clements, J., Lowe, D., McFiggans, G., Percival, C.J., Shallcross, D.E., 2019. Investigating the behavior of the CRI-MECH gas-phase chemistry scheme on a regional scale for different seasons using the WRF-Chem model. Atmos. Res. 229, $145-156$.

Khare, P., Kumar, N., Kumari, K.M., Srivastava, S.S., 1999. Atmospheric formic and acetic acids: an overview. Rev. Geophys. 37, 227-248.

Kuenen, J.J.P., Visschedijk, A.J.H., Jozwicka, M., Denier Van Der Gon, H.A.C., 2014. TNO-MACC II emission inventory; a multi-year (2003-2009) consistent highresolution European emission inventory for air quality modeling. Atmos. Chem. Phys. 14, 10963-10976.

Kuik, F., Lauer, A., Churkina, G., Denier Van Der Gon, H.A.C., Fenner, D., Mar, K.A., Butler, T.M., 2016. Air quality modeling in the Berlin-Brandenburg region using WRF-Chem v3.7.1: sensitivity to resolution of model grid and input data. Geosci. Model Dev. 9, 4339-4363.

Le Breton, M., Bacak, A., Muller, J.B., Bannan, T.J., Kennedy, O., Ouyang, B., Xiao, P. Bauguitte, S.J.-B., Shallcross, D.E., Jones, R.L., Daniels, M.J.S., Ball, S.M., Percival, C.J., 2014. The first airborne comparison of $\mathrm{N}_{2} \mathrm{O}_{5}$ measurements over the UK using a CIMS and BBCEAS during the RONOCO campaign. Anal. Methods 6 , 9731-9743.

Lee, A., Goldstein, A.H., Kroll, J.H., Ng, N.L., Varutbangkul, V., Flagan, R.C., Seinfeld, J. H., 2006. Gas-phase products and secondary aerosol yields from the photooxidation of 16 different terpenes. J. Geophys. Res. Atmos. 111, D17305.

Lee, J.D., Young, J.C., Read, K.A., Hamilton, J.F., Hopkins, J.R., Lewis, A.C., Bandy, B.J., Davey, J., Edwards, P., Ingham, T., Self, D.E., Smith, S.C., Pilling, M.J., Heard, D.E., 2009. Measurements and calculation of OH reactivity at a United Kingdom coastal site. J. Atmos. Chem. 64, 53-76.

Lim, H.-J., Carlton, A.G., Turpin, B.J., 2005. Isoprene forms secondary organic aerosol through cloud processing: model simulations. Environ. Sci. Technol. 39, 4441-4446.

Madronich, S., Calvert, J.G., 1990. Permutation reactions of organic peroxy radicals in the troposphere. J. Geophys. Res. 95, 5697-5717.

Madronich, S., Chatfield, R., Calvert, J.G., Moortgat, G.K., Veyret, R., Lesclaux, R., 1990. A photochemical origin of acetic acid in the troposphere. Geophys. Res. Lett. 17, 2361-2364.

Meng, Z., Seinfeld, J.H., Saxena, P., 1995. Gas/Aerosol distribution of formic and acetic acids. Aerosp. Sci. Technol. 23, 561-578.

Mielnik, A., Link, M., Mattila, J., Fulgham, S.R., Farmer, D.K., 2018. Emission of formic and acetic acids from two Colorado soils. Environ Sci Process Impacts 20, 1537-1545.

Millet, D.B., Guenther, A., Siegel, D.A., Nelson, N.B., Singh, H.D., de Gouw, J.A., Warneke, C., Williams, J., Eerdekens, G., Sinha, V., Karl, T., Flocke, F., Apel, E., Riemer, D.D., Palmer, P.I., Barkley, M., 2010. Global atmospheric budget of acetaldehyde: 3-D model analysis and constraints from in-situ and satellite observations. Atmos. Chem. Phys. 10, 3405-3425.

Mungall, E.L., Abbatt, J.P.D., Wentzell, J.B., Wentworth, G.R., Murphy, J.G., Kunkel, D., Gute, E., Tarasick, D.W., Sharma, S., Cox, C.J., Uttal, T., Liggio, J., 2018. High gasphase mixing ratios of formic and acetic acid in the High Arctic. Atmos. Chem. Phys. $18,10237-10254$.

Nah, T., Guo, H., Sullivan, A.P., Chen, Y., Tanner, D.J., Nenes, A., Russell, A., Ng, N.L., Huey, L.G., Weber, R.J., 2018. Characterization of aerosol composition, aerosol acidity, and organic acid partitioning at an agriculturally intensive rural southeastern US site. Atmos. Chem. Phys. 18, 11471-11491.

Paulot, F., Wunch, D., Crounse, J.D., Toon, G.C., Millet, D.B., DeCarlo, P.F., Vigouroux, C., Deutscher, N.M., González Abad, G., Notholt, J., Warneke, T., Hannigan, J.W., Warneke, C., de Gouw, J.A., Dunlea, E.J., De Mazière, M., Griffith, D.W.T., Bernath, P., Jimenez, J.L., Wennberg, P.O., 2011. Importance of secondary sources in the atmospheric budgets of formic and acetic acids. Atmos. Chem. Phys. 11, 1989-2013.

Peuch, V.H., Engelen, R., Calnan, R., Lambert, J.C., de Rudder, A., 2016. Final Report MACC-III Monitoring Atmospheric Composition and Climate 3. Available from. https ://atmosphere.copernicus.eu/sites/default/files/repository/MACCIIFinalReport. pdf.

Sanhueza, E., Andreae, M.O., 1991. Emission of formic and acetic acids from tropical Savanna soils. Geophys. Res. Lett. 18, 1707-1710. 
Sanhueza, E., Figueroa, L., Santana, M., 1996. Atmospheric formic and acetic acid in Venezuela. Atmos. Environ. 30, 1861-1873.

Seinfeld, J.H., Pandis, S.N., 2016. Atmospheric Chemistry and Physics: From Air Pollution to Climate Change, 3rd ed. Wiley. (1152 pp).

Sindelarova, K., Granier, C., Bouarar, I., Guenther, A., Tilmes, S., Stavrakou, T., Müller, J.-F., Kuhn, U., Stefani, P., Knorr, W., 2014. Global data set of biogenic VOC emissions calculated by the MEGAN model over the last 30 years. Atmos. Chem. Phys. 14, 9317-9341.

Stewart, H.E., Hewitt, C.N., Bunce, R.G.H., Steinbrecher, R., Smiatek, G., Schoenemeyer, T., 2003. A highly spatially and temporally resolved inventory for biogenic isoprene and monoterpene emissions: model description and application to Great Britain. J. Geophys. Res. Atmos. 108, 4644.

Talbot, R.W., Beecher, K.M., Harriss, R.C., Cofer III, W.R., 1988. Atmospheric geochemistry of formic and acetic acids at a mid-latitude temperate site. J. Geophys. Res. Atmos. 93, 1638-1652.

Talbot, R.W., Mosher, B.W., Heikes, B.G., Jacob, D.J., Munger, J.W., Daube, B.C., Keene, W.C., Maben, J.R., Artz, R.S., 1995. Carboxylic acids in the rural continental atmosphere over the eastern United States during the Shenandoah cloud and photochemistry experiment. J. Geophys. Res. 100, 9335-9343.

von Kuhlmann, R., Lawrence, M.G., Crutzen, P.J., Rasch, P.J., 2003. A model for studies of tropospheric ozone and nonmethane hydrocarbons: Model evaluation of ozonerelated species. J. Geophys. Res. 108, 4729.
Watson, L.A., Shallcross, D.E., Utembe, S.R., Jenkin, M.E., 2008. A common representative intermediate (CRI) mechanism for VOC degradation. Part 2: gas phase mechanism reduction. Atmos. Environ. 42, 7196-7204.

Welz, O., Eskola, A.J., Sheps, L., Rotavera, B., Savee, J.D., Scheer, A.M., Osborn, D.L., Lowe, D., Booth, A.M., Xiao, P., Khan, M.A.H., Percival, C.J., Shallcross, D.E., Taatjes, C.A., 2014. Rate coefficients of C1 and C2 Criegee intermediatereactions with formic and acetic acid near the collision limit: direct kinetics measurements and atmospheric implications. Angew. Chem. Int. Ed. 53, 4547-4550.

Yokelson, R.J., Crounse, J.D., DeCarlo, P.F., Karl, T., Urbanski, S., Atlas, E., Campos, T., Shinozuka, Y., Kapustin, V., Clarke, A.D., Weinheimer, A., Knapp, D.J., Montzka, D. D., Holloway, J., Weibring, P., Flock, F., Zheng, W., Toohey, D., Wennberg, P.O., Wiedinmyer, C., Mauldin, L., Fried, A., Richter, D., Walega, J., Jimenez, J.L., Adachi, K., Buseck, P.R., Hall, S.R., Shetter, R., 2009. Emissions from biomas burning in the Yucatan. Atmos. Chem. Phys. 9, 5785-5812.

Yu, S., 2000. Role of organic acids (formic, acetic, pyruvic and oxalic) in the formation of cloud condensation nuclei (CCN): a review. Atmos. Res. 53, 185-217.

Zervas, E., Montagne, X., Lahaye, J., 2001. Emission of specific pollutants from a compression ignition engine. Influence of fuel hydrotreatment and fuel/air equivalence ratio. Atmos. Environ. 35, 1301-1306.

Zhang, Y., Sartelet, K., Zhu, S., Wang, W., Wu, S.-Y., Zhang, X., Wang, K., Tran, P., Seigneur, C., Wang, Z.-F., 2013. Application of WRF/Chem-MADRID and WRF/ Polyphemus in Europe- Part 2: evaluation of chemical concentrations and sensitivity simulations. Atmos. Chem. Phys. 13, 6845-6875. 